DOI: 10.2478/v10014-008-0003-8

Agrovoc descriptors: linum usitatissimum, flax, fibre crops, linseed, oil crops, spacing, stems, crop yield, organic agriculture, biodiversity, cultural heritage

Agris category codes: F01, F50

University of Ljubljana

Biotechnical Faculty

Department of Agronomy

COBISS Code 1.01

\title{
Influence of row spacing on the yield of two flax cultivars (Linum usitatissimum L.)
}

\author{
Darja KOCJAN AČKO ${ }^{1}$, Stanislav TRDAN ${ }^{2}$
}

Received April 25, 2008; accepted May 8, 2008

Delo je prispelo 25. aprila 2008; sprejeto 8. maja 2008

\section{ABSTRACT}

In the period 2003-2006 we have performed block trials with two flax (Linum usitatissimum) cultivars: RBK cultivar (domestic flax population from Raztresen farm in Bela Krajina) and Laura cultivar (fibre-type-flax from the Common Catalogue of EU). The trial was carried out at the Experimental Field at the Biotechnical Faculty of Ljubljana (Slovenia). The two cultivars were sown in the first decade of April with manual sowing machine to the row spacing of 8.5 $\mathrm{cm}, 17 \mathrm{~cm}$ and $34 \mathrm{~cm}$. Crop care was traditional. The plants were plucked at the end of the yellow maturity (the last decade of July). There was no significant difference between the average yields of stems produced at the row spacing of $8.5 \mathrm{~cm}(1.92 \mathrm{t} / \mathrm{ha})$ and $17 \mathrm{~cm}(1.99$ $\mathrm{t} / \mathrm{ha})$, but significantly the lowest yield was reached at the row spacing of $34 \mathrm{~cm}(1.52 \mathrm{t} / \mathrm{ha})$. In the period of 4 years the average yield of stems that was reached by the RBK cultivar was 1.83 $\mathrm{t} / \mathrm{ha}$, and the one reached by the Laura cultivar was unsignificantly lower $(1.79 \mathrm{t} / \mathrm{ha})$. Compared to the average yield of the flaxseed from both cultivars produced at the row spacing of $8.5 \mathrm{~cm}$ $(1.34 \mathrm{t} / \mathrm{ha})$ and $34 \mathrm{~cm}(1.01 \mathrm{t} / \mathrm{ha})$, the average yield of the seeds obtained from the $17 \mathrm{~cm}$ row spacing was significantly the highest $(1.52 \mathrm{t} / \mathrm{ha})$; for $0.11 \mathrm{t} \mathrm{seed} /$ ha the RBK cultivar $(1.35 \mathrm{t} / \mathrm{ha})$ was significntly more productive than the Laura cultivar. The influence of growing conditions to the yield of stems and seed was most favourable in the year of the drought (2003), when - with the cultivar RBK and at the row spacing of $17 \mathrm{~cm}$ - we produced significantly the highest quantity of stems $(2.64 \mathrm{t} / \mathrm{ha})$ and seeds $(1.93 \mathrm{t} / \mathrm{ha})$. We discovered that the unbranched stem of the RBK cultivar corresponds to the fibre-type-flax, the hight of plants $(50$ to $60 \mathrm{~cm})$, absolute mass $(6.3$ to $6.8 \mathrm{~g})$ and the yield of the seed (above $1 \mathrm{t} / \mathrm{ha}$ ) show good biological capability for the seed production. Production and processing of flax should not remain just an attractive cultural and historical presentation of this activity at some turist farms in Bela Krajina (JV of Slovenia); it should also present a challenge to young farmers to find the place for this crop in organic production of food and other raw materials with the use of mechanisation and modern technological procedures. The production and processing of flax presents the possibility for increased biotic diversity of the cultural landscape and revitalization of rural areas.

\footnotetext{
1 High. Educ. Lect., Ph.D., Biotechnical Faculty, Dept. of Agronomy, Jamnikarjeva 101, SI-1111 Ljubljana, e-mail: darja.kocjan@bf.uni-lj.si

${ }^{2}$ Assist. Prof., Ph.D., ibid.
} 
Key words: flax, Linum usitatissimum, domestic flax population, cultivar, fibre-type-flax, seedtype-flax, linseed and fibre types, intermediate-type-flax, dual purpose cultivars, field trial, row spacing, seed yield, stem yield, Slovenia

\section{IZVLEČEK}

VPLIV MEDVRSTNEGA RAZMIKA NA PRIDELEK STEBEL IN SEMENA LANU (Linum usitatissimum L.)

$\mathrm{Na}$ poskusnem polju Biotehniške fakultete $v$ Ljubljani (Slovenija) so bili v obdobju 2003-2006 izvedeni bločni poljski poskusi s kultivarjema lanu (Linum usitatissimum L.) RBK (domača populacija lanu s kmetije Raztresen $\vee$ Beli Krajini) in Laura (vlaknati tip lanu iz Skupnega kataloga kultivarjev poljščin EU). Lan je bil $v$ vseh letih posejan $v$ prvi dekadi aprila $z$ ročno sejalnico na medvrstni razmik $8,5 \mathrm{~cm}, 17 \mathrm{~cm}$ in $34 \mathrm{~cm}$. Oskrba posevka je bila tradicionalna. Rastline smo populili konec rumene zrelosti (zadnja dekada julija). Med povprečnima pridelkoma stebel pri razmiku $8,5 \mathrm{~cm}(1,92 \mathrm{t} / \mathrm{ha})$ in $17 \mathrm{~cm}(1,99 \mathrm{t} / \mathrm{ha})$ ni bilo značilnih razlik, značilno najmanjši pridelek stebel pa je lan dosegel pri razmiku $34 \mathrm{~cm}(1,52 \mathrm{t} / \mathrm{ha})$. Povprečni pridelek stebel v obdobju 4 let je pri kultivarju RBK znašal 1,83 t/ha, pri kultivarju Laura pa je bil neznačilno manjši, to je 1,79 t/ha. $V$ primerjavi $s$ povprečnim pridelkom semena obeh kultivarjev pri razmiku $8,5 \mathrm{~cm}(1,34 \mathrm{t} / \mathrm{ha})$ in $34 \mathrm{~cm}(1,01 \mathrm{t} / \mathrm{ha})$, je bil povprečni pridelek semena pri razmiku $17 \mathrm{~cm}$ značilno največji $(1,52 \mathrm{t} / \mathrm{ha})$; kultivar RBK $(1,35 \mathrm{t} / \mathrm{ha})$ je bil za $0,11 \mathrm{t}$ semena/ha značilno produktivnejši od kultivarja Laura. Vpliv rastnih razmer na pridelek stebel in semena je bil najbolj ugoden $v$ najbolj sušnem letu (2003), ko smo pri razmiku $17 \mathrm{~cm} \mathrm{~s}$ kultivarjem RBK pridelali značilno največ stebel $(2,64 \mathrm{t} / \mathrm{ha})$ in semena $(1,93 \mathrm{t} / \mathrm{ha})$. Ugotovili smo, da nerazvejeno steblo kultivarja RBK sicer ustreza vlaknatemu tipu lanu, višina rastlin (50 do $60 \mathrm{~cm}$ ), absolutna masa $(6,3$ do $6,8 \mathrm{~g})$ in pridelek semena (nad $1 \mathrm{t} / \mathrm{ha}$ ) pa kažejo na dobro biološko zmogljivost za pridelavo semen. Pridelava in predelava lanu ne sme ostati le privlačen kulturno-zgodovinski prikaz te dejavnosti na nekaterih turističnih kmetijah v Beli Krajini (JV Slovenija), ampak tudi izziv za mlade, da s pomočjo mehaniziranih in sodobnih tehnoloških postopkov tej poljščini najdejo mesto $v$ ekološki pridelavi hrane in neprehranskih surovin. Navsezadnje je pridelava in predelava lanu možnost za večjo biotsko pestrost kulturne krajine in ohranjanje poseljenosti podeželja.

Ključne besede: lan, Linum usitatissimum, domača populacija, kultivar, vlaknati tip lanu, semenski tip lanu, mešani tip lanu, poljski poskus, medvrstni razmik, pridelek semena, pridelek stebel

1

\section{INTRODUCTION}

Flax (Linum usitatissimum L.) is universally useful fibre and oilseed plant (Sadar, 1935, 1951). Production and processing of fibres and linseed reach far back into the period of the ancient civilizations, their achievements were the basis for the progress untill today.

Production of flax for fibres and seed at Ljubljana marsh (Ljubljansko barje) was known from the period of »koliščarji« (people who lived on crannogs) approximatelly 2000 B.C. At the area of Slovenia flax was the most widespread in the $18^{\text {th }}$ and in the beggining of the $19^{\text {th }}$ century, when it covered at least 6000 ha, production of flax products was a very profitable craft (Bogataj, 1989; Maček, 1993). At the end of the $19^{\text {th }}$ century, the traditional manual flax production and processing of stems into fibres, that was not mechanised on time, was replaced by cotton from tropical areas, which was cheaper and more suitable for machine processing and also by the development and production of synetetic fibres (Sadar, 1951; Kvader Malej, 1992; Rengeo, 1995; Gagro, 1998; Kocjan Ačko, 1998, 
1999ab; Štimac, 2004). During the first half of the $20^{\text {th }}$ century, 1000 ha of fields were sown by flax, but after the second world war farmers gradualy abandoned its production. Sadar (1951) states, that farmers mostly sow the dual purpose cultivars of flax. They used it for the traditional production of both - stems and flaxseed, the average yield $-0.5 \mathrm{t}$ stems/ha and $0.5 \mathrm{t}$ flakseed/ha was lower, compared to the sole purpose production - either for the stems or for the flaxseed.

The modern flax cultivars were developed regarding the purpose of use, that is fibre-type-flax or seed-type-flax. Fibre type flax is usualy higher with less lateral branches, has longer fibres in the stem but lower yield of the seed. The intermediate-type-flax, that combines caracteristics of both types is caracteristic for indigenous cultivars, that are still preserved in areas with traditional production. Average world yield of the linseed in the period 2000 to 2006 reached from $0.7 \mathrm{t}$ to $0.9 \mathrm{t} / \mathrm{ha}$, in the same period the average yield of fibre including the tow was between 1.1 to $2 \mathrm{t} / \mathrm{ha}$.

In Slovenia the traditional production and processing of flax still exists only on some turist farms in Bela Krajina (around Adlešiči), where it mostly has the educational, cultural and historical importance (Kocjan Ačko, 2003; Štimac, 2004; Rožanc Nanut, 2007). Farmers there sow the flax within the 5 to 7 year crop rotation, they use traditional crop care with no synthetic mineral fertilisers and pesticides, which is in harmony with all standards of organic production. Decades ago they used livestock to prepare the land for sowing, which is now replaced by the use of machines, but the sowing is still performed manualy crosswise. Weediness of crop is reduced by the crop rotation and manual 2 to 3 -time weeding. Like in the past, the main flax product are the fibres, at the same time also flaxseed is produced, used for re-sowing and nutrition, to variegate the food, mainly bakers wares, its healing purpose is preserved by drinks and teas.

On the Biotechnical Faculty in Ljubljana we started the research of agritechnical procedures in flax production for the purpose of revitalization and modernization of stem and seed production in 2003. The purpose of the field trials in the period 2003-2006 was to study the influence of row spacing to the yield of stems and seed for the two flax cultivars with the goal to determine the most suitable combination for the widespread production in Slovenia. Since the living space that flax needs for its growth and development depends on the purpose of production, we followed the previous findings of foreign experts, when sowing in rows. When we sow in rows the fibre type flax, the row spacing of 6 to $10 \mathrm{~cm}$ was introduced, on the other side, for the seed type flax bigger spacing is required, that is 20 to $40 \mathrm{~cm}$. Since simultaneous production of stems and seed is no longer so common and widespread, we considered Sadar's (1951) recommendations, who believed that for such cases 15 to $20 \mathrm{~cm}$ is the most suitable row spacing. From the research of Easson and Molloy (2000), Weighman and Kindred (2005), Butorac et al. (2006), and Burton (2007) it is clearly seen that the sowing density (number of plants per $\mathrm{m}^{2}$ ), quantity of seed for sowing $(\mathrm{kg} / \mathrm{ha})$ together with the row spacing have the important influence on the yield of stems, fibre and linseed. We wanted to test all the abovementioned facts with our research. 
Field trials were performed in the period 2003-2006 on the Experimental Field of the Biotechnical Faculty in Ljubljana $\left(46^{\circ} 04^{\prime} \mathrm{N}, 14^{\circ} 31 \mathrm{E}, 299\right.$ alt.), Slovenia. In every year the seed of two cultivars was sown according to the random block method in three repetitions. The size of individual parcel was $1 \mathrm{~m} \times 4 \mathrm{~m}\left(4 \mathrm{~m}^{2}\right)$. The trials covered the domestic flax population from Bela Krajina and the Dutch cultivar Laura, entered in the EU Common catalogue of crop cultivars and declared for the fibre production. The seed of the domestic flax cultivar that was obtained from organic turistic farm Raztresen in the Jankoviči village near Adlešiči in Bela Krajina, was named the RBK cultivar.

\subsection{Agrotechnique, field trials, plant observations and evaluation}

Weedines, which is very common in the crops of flax on lands that were previously cultivated and sown with grains, was reduced by sowing flax after the root crops; during the years 2003 and 2005 the previous crop was the sunflower (Helianthus annuus L.) and in years 2004 and 2006, the potato (Solanum tuberosum L.). Since flax has the tendancy to lodging and due to demands of organic production we have chosen not to use any direct fertilizing with mineral or organic fertilizers. Previous crops were fertilized with $20 \mathrm{t}$ of manure/ha and $100 \mathrm{~kg} \mathrm{KAN}(27 \%$ $\mathrm{N}) /$ ha. Land treatment included autumn ploughing and spring pre-sowing treatment.

All trials were sown in the first decade of April $\left(2^{\text {nd }}\right.$ April in 2003, $6^{\text {th }}$ April in 2004, $10^{\text {th }}$ April in 2005 and $3^{\text {rd }}$ April in 2006) with the manualy operated sowing machine Wintersteiger with the operating width of $1 \mathrm{~m}$. Seed of both cultivars was sown at three different row spacings: 8.5, 17 in $34 \mathrm{~cm}$. In individual row, the spacing was from 2 to $3 \mathrm{~cm}$, the depth of sowing was approximatelly $1 \mathrm{~cm}$. Aproximatelly $0.5 \mathrm{~m}$ wide paths were left between the parcels, protective zone was sown around the experimental field. For the $8.5 \mathrm{~cm}$ row spacing, 12 rows were sown on individual parcel, for the medium spacing $(17 \mathrm{~cm}) 6$ rows were sown, and for $34 \mathrm{~cm}$ row spacing three rows were sown. Despite the excellent seed quality (95 to 100\%), the crust, that occurred immediately after sowing, prevented equal germination and growth. That is why we filled in the missing parts with manual re-sowing when the plants were approximatelly $5 \mathrm{~cm}$ high. Weediness, mostly at the $17 \mathrm{~cm}$ and $34 \mathrm{~cm}$ row spacings, was reduced with manual weeding and hoeing, for the first time when the plants were 10 to $20 \mathrm{~cm}$ high and the second time before blooming. Lodging was evaluated at the beggining of the yellow maturity and we have esablished that in the year 2003 there was no lodging of the crop; in the following years we detected only slight tendency to lodging in the case of dense sowing, but there were no differences between the cultivars.

We have been monitoring the growth and development, the plants were manualy plucked in the middle of the yellow maturity of stems from every parcel separately, that is on the $28^{\text {th }}$ of July in 2003 , on the $25^{\text {th }}$ July in 2004 , on the $28^{\text {th }}$ July in 2005 and on the $29^{\text {th }}$ of July in 2006. For twenty plants we have measured the stem hight, that is the distance from the cotiledone node to the highest head in inflorescence and we counted the lateral branches. Plants that were laid down on the parcel were tied in sheafs after 3 to 4 hours and then put into the jutebags. After one month the seed, leaves and huskes were shaken off from dry sheafs and from the rest of stems the seed heads were stripped off, crushed and the seed was cleaned and weighted. We measured the humidity of the seed samples of each cultivar from all three row spacings with the Pfeuffer he 50 hygrometer. The yield was calculated to $10 \%$ seed humidity. Every year, using the standard ISTA procedure, we analysed the absolute mass of produced linseed for each individual cultivar, considering different row spacing. We also weighted the dry crop of stems with no leaves and seeds. For easier comparisson with stems and seed yields, reached in practice, the yields from the experiment were calculated to tons per hectar.

\subsection{Data analysis}

All the data about the stem and seed yield (t/ha) for the two flax cultivars were analysed using a general analysis of variance (the results of the yield from three different ways of sowing for all years of the trials were pooled) and individual analysis of variance (the results of the yield 
for only one way of sowing were treated). Means were separated by Student-Newman-Keuls's multiple range test at $P<0.05$. Before analysis, each variable was tested for homogeneity of treatment variances. If variances were non-homogeneous, data was transformed to $\log (Y)$ before ANOVA. All statistical analysis was performed with Stat graphics Plus for Windows 4.0 (Statistical Graphics Corp., Manugistics, Inc.). Data is presented as un-transformated means \pm SE.

\subsection{Weather conditions in the period 2003 to 2006}

Average monthly air temperature in the period April-June per individual year was at the 30-year average, that is for April $\left(10.1^{\circ} \mathrm{C}\right)$, for May $\left(16^{\circ} \mathrm{C}\right)$ and for June $\left(20.1^{\circ} \mathrm{C}\right)$. Average July temperature $\left(22.1^{\circ} \mathrm{C}\right)$ was above the long term average (Mesečni agrometeorološki bilten..., 2003-2006). Contrary to the temperature data, the analysis of average monthly percipitation in Ljubljana from April to July showed important differences between months and years. The most significant were deviations in 2003 , when the average quantity of percipitations from April to July were only $222 \mathrm{~mm}$, compared to the years with more percipitation; $579 \mathrm{~mm}$ in 2004, $442 \mathrm{~mm}$ in 2005, and $449 \mathrm{~mm}$ in 2006. Compared to dry spring in 2003 (in March there was only $3 \mathrm{~mm}$ percipitations, in April $81 \mathrm{~mm}$, in May $66 \mathrm{~mm}$ and in June $63 \mathrm{~mm}$ ), there was more rain in the year $2004(171 \mathrm{~mm}, 110 \mathrm{~mm}$, and $172 \mathrm{~mm})$, similarly in the years $2005(119 \mathrm{~mm}, 97$ $\mathrm{mm}$ and $84 \mathrm{~mm})$ and $2006(121 \mathrm{~mm}, 177 \mathrm{~mm}$ and $46 \mathrm{~mm})$. The average July quantity of percipitations per individual years were also comparable, that is $120 \mathrm{~mm}(2003), 126 \mathrm{~mm}$ (2004), $142 \mathrm{~mm}$ (2005) and $105 \mathrm{~mm}$ (2006).

\section{RESULTS AND DISCUSSION}

3.1 The analysis of the results of the linseed and stem yield regarding the year of the experiment, row spacing and cultivar

With the general statistical analysis we determined that the year of the experiment, row spacing (for both $P<0.0001)$ and cultivar $(P<0.0039)$ all had the significant influence to the yield of the linseed. Significantly the highest yield of linseed was recorded in the years $2003(1.33 \pm 0.10 \mathrm{t} / \mathrm{ha})$ and $2004(1.43 \pm 0.06 \mathrm{t} / \mathrm{ha})$, significantly the lowest was the yield in the years $2005(1.19 \pm 0.04 \mathrm{t} / \mathrm{ha})$ and $2006(1.25 \pm 0.04)$. Between the years 2003 and 2006 no significant differences in the linseed yield was detected. Significantly the highest seed yield $(1.52 \pm 0.05 \mathrm{t} / \mathrm{ha})$ was recorded for the $17 \mathrm{~cm}$ row spacing, while significantly the lowest one $(1.01 \pm 0.03 \mathrm{t} / \mathrm{ha})$ was recorded for the $34 \mathrm{~cm}$ row spacing. The Laura cultivar was less productive $(1.24 \pm 0.03 \mathrm{t} / \mathrm{ha})$ and in that sence it is significantly different from the RBK cultivar $(1.35 \pm 0.06 \mathrm{t} / \mathrm{ha})$.

With the use of the same analysis we confirmed that the year of the experiment $(P$ $<0.0002)$ and the row spacing $(P<0.0001)$ both had a significant influence to the yield of stems, but not also the cultivar $(P<0.4407)$. Between the years 2004 $(1.82 \pm 0.07 \mathrm{t} / \mathrm{ha}), 2005(1.73 \pm 0.04 \mathrm{t} / \mathrm{ha})$ and $2006(1.68 \pm 0.07 \mathrm{t} / \mathrm{ha})$, no significant differences in the yield were detected, significantly the highest yield of stems was recorded in the year $2003(2.02 \pm 0.11 \mathrm{t} / \mathrm{ha})$. For the smallest $(1.92 \pm 0.03 \mathrm{t} / \mathrm{ha})$ and medium row spacing $(2.00 \pm 0.06 \mathrm{t} / \mathrm{ha})$ the yields of stems were significantly the highest and significantly the lowest yield $(1.53 \pm 0.06 \mathrm{t} / \mathrm{ha})$ was recorded for the largest row spacing. There were no significant differences in stem yields between the tested cultivars $(1.79 \pm 0.07 \mathrm{t} /$ ha for the RBK cultivar and $1.83 \pm 0.04 \mathrm{t} /$ ha for the Laura cultivar). 

their correlation

Between the linseed yield $(y)$ and the stem yield $(x)$ we have detected a significant $(P<0.0001)$ moderately strong positive correlation with the coefficient of correlation $(r) 0.74(y=0.15+0.63 x)$. Between the linseed yield and the number of branches per one plant weak corelations were discovered. In first and third case there was a significant correlation contrary to the second and the last case.

\subsection{Analyses of results of the linseed and stem yield for individual row spacing}

With individual analysis (separate analyses of results for the yields of linseed and yields of stems per different row spacings) we have discovered that in case of the smallest and medium row spacing, there was a significant influence of the year of the trails $(P \leq 0.0227)$ and of the cultivar $(P \leq 0.0497)$ on the linseed yield. In the case of the smallest row spacing, only in the first year of the experiment, the RBK cultivar gave significantly higher yield $(1.65 \pm 0.03 \mathrm{t} / \mathrm{ha})$ compared to the Laura cultivar $(1.25 \pm 0.03 \mathrm{t} / \mathrm{ha})$, while during the other years of the experiment, there were no significant differences between the two cultivars (figure 1, left). For the medium row spacing, there were no significant differences in the linseed yield between the two cultivars in the year 2004, but in the years 2003, 2005 and 2006, the yield of the RBK cultivar was significantly higher $(1.93 \pm 0.03 \mathrm{t} /$ ha in the first, $1.42 \pm 0.04$ $\mathrm{t} / \mathrm{ha}$ in the third and $1.51 \pm 0.05 \mathrm{t} / \mathrm{ha}$ in he fourth year) compared to Laura cultivar $(1.40 \pm 0.14 \mathrm{t} / \mathrm{ha}$ in the first, $1.21 \pm 0.02 \mathrm{t} / \mathrm{ha}$ in the third and $1.30 \pm 0.02 \mathrm{t} / \mathrm{ha}$ in the fourth year) (figure 2, left). For the largest row spacing there was no significant difference in the linseed yield between the cultivars in the years 2005 and 2006, in the year 2003 the yield was significantly higher at the Laura cultivar $(1.05 \pm 0.03$ $\mathrm{t} / \mathrm{ha}$ ), in the year 2004 it was higher for the RBK cultivar (1.15 $\pm 0.02 \mathrm{t} / \mathrm{ha}$ ) (figure 3 , left).

The yield of stems was for all three row spacings significantly determined by the year of the trial (in every case $P<0.0001)$ and by the cultivar $(P<0.0492)$. In the years 2004, 2005 and 2006 we detected no significant differences between the cultivars in case of the smallest row spacing; during the first year of the trial, the stem yield of Laura cultivar was significantly higher $(2.24 \pm 0.08 \mathrm{t} / \mathrm{ha})$ compared to the RBK cultivar $(2.03 \pm 0.03 \mathrm{t} / \mathrm{ha})$ (figure 1 , right). For the medium row spacing, the RBK cultivar was significantly more productive than the Laura cultivar (figure 2 , right) during all years of the experiment. The year 2003 gave exceptionally high yields, the RBK cultivar reached the yield of $2.64 \pm 0.06 \mathrm{t} /$ ha and the Laura cultivar $2.13 \pm 0.06 \mathrm{t} / \mathrm{ha}$. In first two years of the trials, Laura cultivar was significantly more productive, compared to the RBK cultivar, also when the largest row spacing was used, while in the years 2005 and 2006 we detected no significant differences in the stem yield between the two tested cultivars (figure 3, right). In the year 2003 absolutely the highest yield for the largest row spacing was recorded for the Laura cultivar $(1.97 \pm 0.12 \mathrm{t} / \mathrm{ha})$, absolutely the lowest was recorded in the same year for the RBK cultivar $(1.13 \pm 0.03 \mathrm{t} / \mathrm{ha})$. 
3.4 Influence of certain yield factors to the stem and linseed yield and their correlation regarding the row spacing

For the smallest row spacing, a nonsignificant $(P=0.1147)$ relatively weak positive correlation with the coefficient of correlation $(r) 0.33(\mathrm{y}=0.65+0.36 \mathrm{x})$ was detected between the linseed yield and stem yield. For the medium row spacing, the correlation between the linseed yield and yield of stems was significant $(P<$ $0.0001)$, moderately strong and positive, the correlation factor $(r)$ was calculated at $0.76(y=0.34+0.59 x)$. For the largest row spacing, we detected significant $(90 \%$ confidence level) relatively weak positive correlation between the both parameters with the correlation coefficient $(r) 0.36(\mathrm{y}=0.76+0.17 \mathrm{x})$.

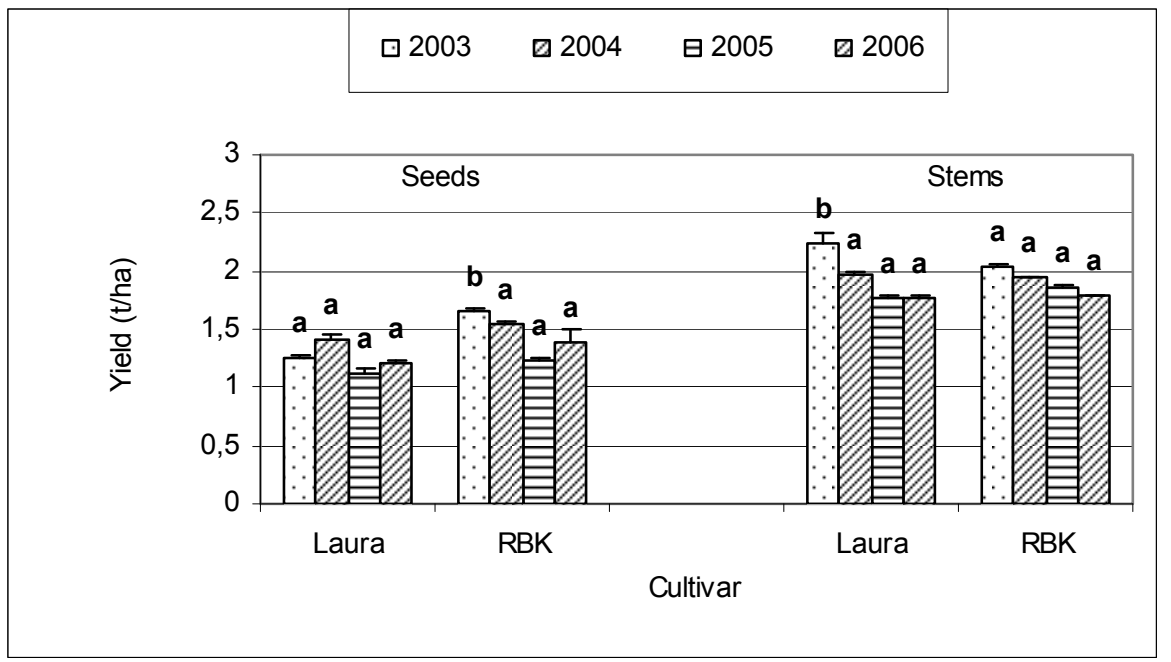

Figure 1. Yield of seeds and stems of the two flax cultivars (Linum usitatissimum L.) at the $8.5 \mathrm{~cm}$ row spacing in the field trials at the Experimental Field of the Biotechnical Faculty in Ljubljana in the period 2003-2006. 


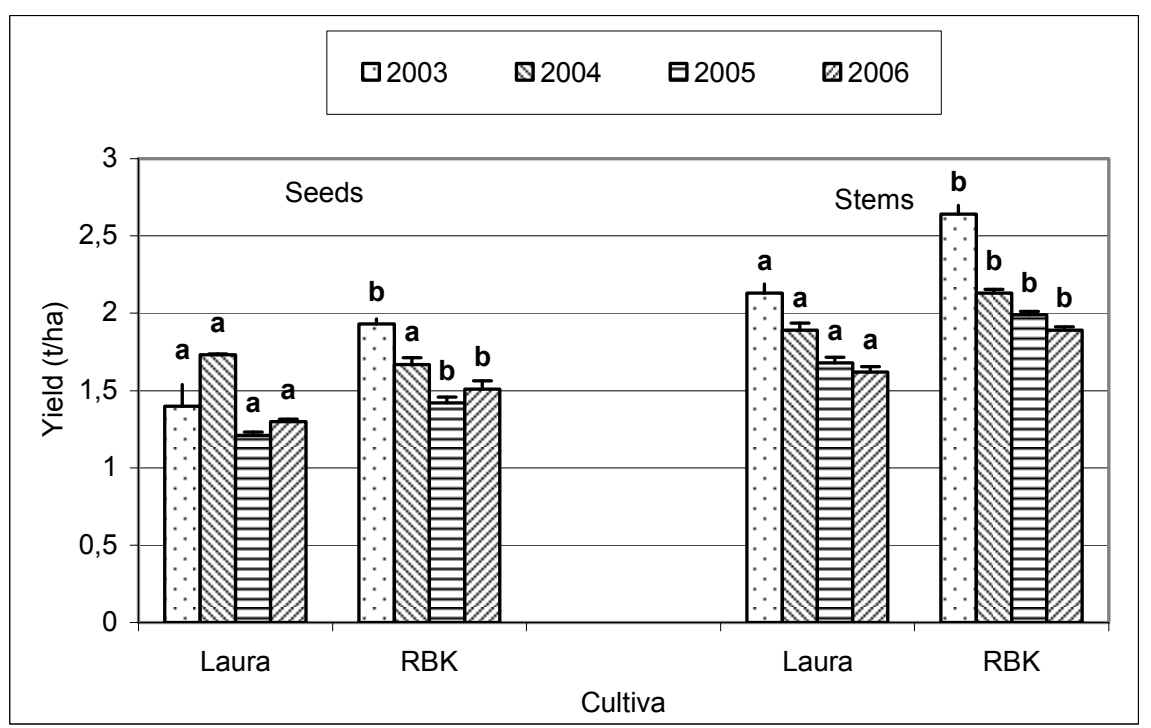

Figure 2. Yield of seeds and stems of the two flax cultivars (Linum usitatissimum L.) at the $17 \mathrm{~cm}$ row spacing in the field trials at the Experimental Field of the Biotechnical Faculty in Ljubljana in the period 2003-2006.

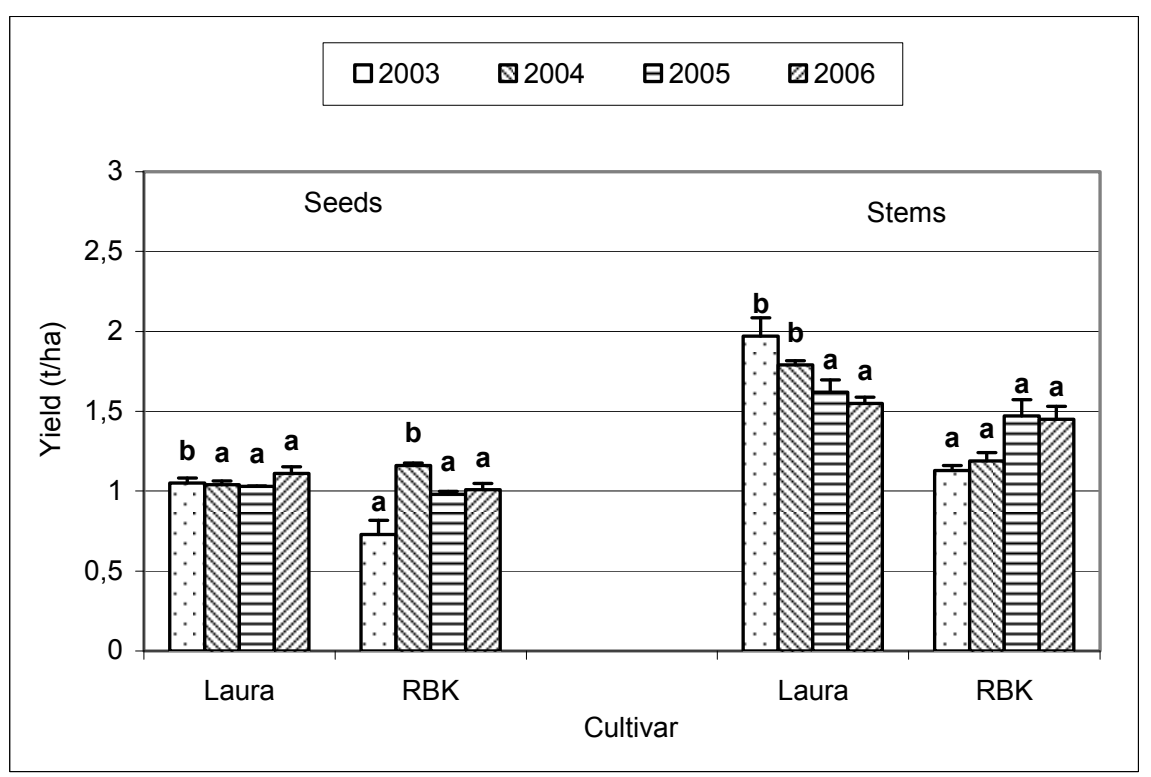

Figure 3. Yield of seeds and stems of the two flax cultivars (Linum usitatissimum L.) at the $34 \mathrm{~cm}$ row spacing in the field trials at the Experimental Field of the Biotechnical Faculty in Ljubljana in the period 2003-2006. 


\subsection{Plant height, branching of the stem and absolute mass}

Analyses of the plant height showed that the plants of the RBK cultivar in the period 2003-2006 reached in average $55.17 \mathrm{~cm}$, which is $23.3 \mathrm{~cm}$ more than the plants of the Laura cultivar $(78.5 \mathrm{~cm})$. We also detected some differences in the plant height in individual cultivar, regarding the row spacing (Table 1). The height of plants was reducing together with the larger row spacing, which was also confirmed by the research of Butorac et al. (2006).

Table. 1.Average height of flax plants (Linum usitatissimum L.) for the RBK and Laura cultivars regarding the row spacing in the field trials at the Experimental Field of the Biotechnical Faculty in Ljubljana in the period 2003-2006.

\begin{tabular}{|c|c|c|c|c|c|c|}
\hline \multirow[t]{4}{*}{ Year } & \multicolumn{6}{|c|}{ Cultivar } \\
\hline & \multicolumn{3}{|c|}{ Laura } & \multicolumn{3}{|c|}{ RBK } \\
\hline & \multicolumn{3}{|c|}{ Plant height $(\mathrm{cm})$ for row spacing } & \multicolumn{3}{|c|}{$\begin{array}{l}\text { Plant height (cm) for row } \\
\text { spacing }\end{array}$} \\
\hline & $8.5 \mathrm{~cm}$ & $17 \mathrm{~cm}$ & $34 \mathrm{~cm}$ & $8.5 \mathrm{~cm}$ & $17 \mathrm{~cm}$ & $34 \mathrm{~cm}$ \\
\hline 2003 & 82.35 & 79.07 & 74.00 & 59.20 & 53.63 & 49.87 \\
\hline 2004 & 85.63 & 81.80 & 77.20 & 60.74 & 57.06 & 51.73 \\
\hline 2005 & 82.33 & 78.80 & 74.73 & 58.87 & 55.97 & 50.46 \\
\hline 2006 & 81.53 & 77.20 & 75.40 & 58.63 & 55.20 & 50.66 \\
\hline Average & 82.96 & 79.22 & 75.33 & 59.36 & 55.46 & 50.68 \\
\hline $\begin{array}{l}\text { Total } \\
\text { average }\end{array}$ & \multicolumn{3}{|c|}{78.50} & \multicolumn{3}{|c|}{55.17} \\
\hline
\end{tabular}

Both cultivars had upright and in the case of the $8.5 \mathrm{~cm}$ row spacing straight unbranced stems, only Laura cultivar formed branches, at medium spacing it formed averagely from 0.34 to 1 branch per one stem, but the largest row spacing influenced the formation of one to two branches per stem (Table 2). Branching of the stem is genetically predetermined (Couture et al., 2002), which was confirmed also by our research, where the RBK cultivar remained branchless also at the biggest row spacing $34 \mathrm{~cm}$.

Absolute mass of the produced linseed showed that the flax population from the Raztresen farm had in average thicker, bigger and heavier seeds $(\mathrm{AM}=6.56 \mathrm{~g})$, compared to the seeds given by the Laura cultivar, which were lighter for approximatelly $1.45 \mathrm{~g}(\mathrm{AM}=5.11 \mathrm{~g})$. In the case of individual cultivar, the differences were also recorded regarding the different row spacings. For both cultivars, the absolute mass of seeds increased by the larger row spacing (Table 3), which was detected also by the authors of other experiments (Weighman and Kindred, 2005; Butorac et al., 2006). 
Table. 2.Average branching of flax stems (Linum usitatissimum L.) for the RBK and Laura cultivars regarding the row spacing in the field trials on the Experimental Field of the Biotechnical Faculty in Ljubljana in the period 2003-2006.

\begin{tabular}{|c|c|c|c|c|c|c|}
\hline \multirow[t]{4}{*}{ Year } & \multicolumn{6}{|c|}{ Cultivar } \\
\hline & \multicolumn{3}{|c|}{ Laura } & \multicolumn{3}{|c|}{ RBK } \\
\hline & \multicolumn{3}{|c|}{$\begin{array}{l}\text { Numer of branches per plant at } \\
\text { the row spacing }\end{array}$} & \multicolumn{3}{|c|}{$\begin{array}{c}\text { Number of branches per plant } \\
\text { at the row spacing }\end{array}$} \\
\hline & $8.5 \mathrm{~cm}$ & $17 \mathrm{~cm}$ & $34 \mathrm{~cm}$ & $8.5 \mathrm{~cm}$ & $17 \mathrm{~cm}$ & $34 \mathrm{~cm}$ \\
\hline 2003 & 0 & 0.34 & 2 & 0 & 0 & 0 \\
\hline 2004 & 0 & 0 & 1.67 & 0 & 0 & 0 \\
\hline 2005 & 0 & 1 & 2 & 0 & 0 & 0 \\
\hline 2006 & 0 & 0.67 & 2 & 0 & 0 & 0 \\
\hline Average & 0 & 0.50 & 1.92 & 0 & 0 & 0 \\
\hline $\begin{array}{l}\text { Total } \\
\text { average }\end{array}$ & \multicolumn{3}{|c|}{0.80} & \multicolumn{3}{|c|}{0} \\
\hline
\end{tabular}

Table. 3. Absolute mass (mass of 1000 grains) of the flax seed (Linum usitatissimum L.) for the RBK and Laura cultivars regarding the row spacing in the field trials at the Experimental Field of the Biotechnical Faculty in Ljubljana in the period 2003-2006.

\begin{tabular}{|c|c|c|c|c|c|c|}
\hline \multirow[t]{4}{*}{ Year } & \multicolumn{6}{|c|}{ Cultivar } \\
\hline & \multirow{2}{*}{\multicolumn{3}{|c|}{$\begin{array}{c}\text { Laura } \\
\begin{array}{c}\text { Absolute mass (g) at row } \\
\text { spacing }\end{array}\end{array}$}} & \multirow{2}{*}{\multicolumn{3}{|c|}{$\begin{array}{c}\text { Absolute mass (g) at row } \\
\text { spacing }\end{array}$}} \\
\hline & & & & & & \\
\hline & $8.5 \mathrm{~cm}$ & $17 \mathrm{~cm}$ & $34 \mathrm{~cm}$ & $8.5 \mathrm{~cm}$ & $17 \mathrm{~cm}$ & $34 \mathrm{~cm}$ \\
\hline 2003 & 4.99 & 5.07 & 5.33 & 6.53 & 6.69 & 6.99 \\
\hline 2004 & 5.02 & 5.11 & 5.48 & 6.13 & 6.58 & 6.65 \\
\hline 2005 & 4.77 & 4.99 & 5.15 & 6.39 & 6.61 & 6.75 \\
\hline 2006 & 4.98 & 5.12 & 5.39 & 6.14 & 6.55 & 6.72 \\
\hline Average & 4.94 & 5.07 & 5.33 & 6.29 & 6.61 & 6.78 \\
\hline $\begin{array}{l}\text { Total } \\
\text { average }\end{array}$ & \multicolumn{3}{|c|}{5.11} & \multicolumn{3}{|c|}{6.56} \\
\hline
\end{tabular}

\section{$4 \quad$ CONCLUSIONS}

Adapting the agrotechnical procedures to selected cultivars and growing conditions, is the precondition for higher and more stable yield of stem and/or linseed (Easson and Molloy, 2000; Weighman and Kindred, 2005; Butorac et al., 2006; Burton, 2007). In field trials with two flax cultivars (Linum usitatissimum L.) at three different row spacings, we have determined that both cultivars have nonsignificantly different stem yield at $8.5 \mathrm{~cm}(1.92 \mathrm{t} / \mathrm{ha})$ and $17 \mathrm{~cm}(1.99 \mathrm{t} / \mathrm{ha}) \mathrm{row}$ spacings. Compared to smaller row spacings, significantly the lowest yield of stems (1.52 $\mathrm{t} / \mathrm{ha}$ ) at the $34 \mathrm{~cm}$ row spacing showed, that this spacing is not suitable (too large). From the average 4-year stem yield, it could be detected that the RBK 
(1.83 t stems/ha) and Laura (1.79 t stems/ha) cultivars are both equal, according their productivity. Since the stem yield in the trials is much higher, compared to the yield calculated for the Raztresen farm (in average 1 ton stems/ha), we suggested to the farmer, to sow the flax with the ordinary grain sowing machine to the row spacing of 8.5 or $17 \mathrm{~cm}$ in the future.

With the analysis of the linseed yield we confirmed that the $17 \mathrm{~cm}$ row spacing is the most suitable. At this row spacing, the average seed yield of both cultivars $1.52 \mathrm{t} / \mathrm{ha}$ was significantly the highest, which is for 0.18 tons more than at the 8.5 $\mathrm{cm}$ row spacing $(1.34 \mathrm{t} / \mathrm{ha})$ and for 0.51 tons more than at the $34 \mathrm{~cm}$ row spacing $(1.01 \mathrm{t} / \mathrm{ha})$. In the 4-year average, the RBK cultivar $(1.35 \mathrm{t} / \mathrm{ha})$ was significantly more productive than the Laura cultivar, for $0.11 \mathrm{t}$ of seeds/ha. The yield of seeds in the trials was almost once as high as the average yield calculated for the Raztresen farm, where in the case of the manual sowing crosswise, it amounts $0.5 \mathrm{t}$ seeds/ha on the average. The results show that the sowing in rows for the production of seed is better than the sowing crosswise and the row spacing of 17 $\mathrm{cm}$ is the most suitable one.

Regarding certain morphological and economicaly significant characteristics, such as absolute mass, plant height and linseed yield (Couture et al., 2002), the domestic cultivar RBK has more characteristics of the seed type flax, but its nonbranched stem is the typical characteristic of the fibre producing flax cultivars. Considering also its fibre yield, it is comparable to the Dutch cultivar Laura, therefore it can be used for fibre production and production of high quality linen, products from the Raztresen farm also confirm its importance for fibre production.

Over one thousand years old tradition of flax production (Sadar, 1935, 1951) and the results of the trials at the Experimental Field of the Biotechnical Faculty in the period 2003-2006 show that in Slovenia there are favourable growing conditions for the production of this old fibre plant and oilseed (Kocjan Ačko, 2003; Štimac, 2004), especially due to recently increasing demand for linseed, textile and technical fibres from organic production.

Regarding the purpose of use of the crop, the oily flax has the advantage, due to increasingly favourable temperature conditions (Burton, 2007). These favourable temperatures are, in the recent years, evident from the periods of drought and mostly by high July temperatures also in Slovenia (in this sense the year 2003 was the warmest and the flax yield was significantly the highest). There is an increased demand for the flaxseeds and flax oil by the domestic buyers, who currently use imported products and there are also possibilities to export the linseed to the north and west of Europe, where the growing conditions, despite the global warming, are less favourable than in Slovenia (Tajnšek, 1990). For the production of the linseed, in addition to the introduction of the machine production, only smaller investments are required, to adjust the operation of present grain sowing and harvesting machines, and every year the number of facilities for the cold pressing of pumpkin seed, oilseed, sunflowers, hemp seeds and flaxseeds is increasing.

Production and processing of flax should not remain just an attractive cultural and historical presentation of the flax production on some tourist farms in Bela Krajina 
(JV Slovenia). It should be recognised as an opportunity for the young farmers to find the place of flax in organic crop production as the production of food and other raw materials for craft and industrial products, or for the production of organic fuel, with the use of mechanised production. At the end, the re-introduction and production of flax can have an important influence on the biotic diversity of the cultural landscape and revitalization of rural areas.

Indiginous population of the RBK cultivar is a part of the cultural inheritence of national treasures and a mean of preservation of biotic diversity. It is also an opportunity for the registration of the first flax cultivar of Slovene origin.

Despite significantly higher seed yield of the RBK cultivar compared to the seed yield given by Laura cultivar, it could be a good idea to choose the seed-typecultivar-flax from the Common catalogue of the EU and verify its yield of seed and fat contents with the field trials.

\section{REFERENCES}

Bogataj, J. (1989): Tkalci in tkalke. Sto srečanj z dediščino na Slovenskem. Ljubljana, Prešernova družba: 226-227.

Burton, A. (2007): Field plot conditions for the expression and selection of strow fibre concentracion in oilseed flax. University of Saskatchewan, Dept. of Plant sciences, Saskatoon, Canada: $60 \mathrm{p}$.

Butorac, J., Pospišil, M., Mustapić, Z. (2006): Utjecaj gustoće sjetje na neka morfološka i fenološka svojstva sorti predivnog lana. Sjemenarstvo 23: 5-6.

Couture, S. J., Asbil, W. L., DiTommaso, A., Watson, A. K. (2002): Comparison of European fibre Flax (Linum usitatissimum L.) cultivars under eastrn Canadian growing conditions. J. Agron. Crop Sci., 188: 350-356.

Easson, D. L., Molloy R. M. (2000): A study of the plant, fibre and seed development in flax and linseed (Linum usitatissimum) grown at range of seed rates. J. Agric. Sci., 135: $361-369$.

Fitosanitarna uprava RS (FURS). Sektor za sorte rastlin - semenarstvo (2008): http://www.furs.si/low/EU/SEME/Sortna lista/

Gagro, M. (1998): Lan. In: Industrijsko i krmno bilje. Zagreb, Hrvatsko agronomsko društvo: $320 \mathrm{p}$.

Kocjan Ačko, D. (1998): Naravna vlakna v svetu in pri nas. Kmetijstvo in okolje/ agriculture and environment, Bled, 12.-13. 3. 1998, Kmetijski inštitut Slovenije: 381-387.

Kocjan Ačko, D. (1999a): Lan. In: Pozabljene poljščine. Ljubljana, Kmečki glas: 83-99.

Kocjan Ačko, D. (1999b): Pomen lana in konoplje v preteklosti in obeti zanju v prihodnosti. Sodobno kmetijstvo, 32, 4: 73-77.

Kocjan Ačko, D. (2003): Lan. Biodar, 3, 1: 8-10.

Maček, J. (1993): Lan. In: Statistika kmetijske rastlinske pridelave v Sloveniji v obdobju 1869-1939. Zbornik BF, Spl. 21. Ljubljana: 46-53. 
KOCJAN AČKO, D., TRDAN, S.: Influence of row spacing on the yield of two flax... 35

Malej-Kveder, S. (1992): Tekstilne surovine, vlakna 1. Ljubljana, Zavod Republike Slovenije za šolstvo in šport: $164 \mathrm{p}$.

Mesečni agrometeorološki bilten 4-7. Ljubljana, Agencija RS za okolje. 2003-2006. http://www.arso.gov.si/podrocja/vreme publikacije/klimatske. razmere.html

Rengeo, D. (1995): Konoplja in lan. Ižakovci. Izdano ob prireditvi Bürjaški dnevi: 51 p.

Rožanc Nanut, K. (2007): Biološko godenje in lastnosti domačega lanu [Biological retting and properties of domestic flax]. Dipl. delo, Univ. Ljubl., Naravoslovnotehniška fak., Odd. tekst., Ljubl.: 80 p.

Sadar, V. (1935): Lan in konoplja. Kmetijska matica. Ljubljana: 185-187.

Sadar, V. (1951): Lan. In: Oljnice, korenovke, predivnice in hmelj. Ljubljana, Založba Kmečka knjiga: 247-248.

Štimac, R. (2004): Vpliv genotipa in gostote setve lana (Linum usitatissimum L.) na pridelek stebel in semen. Diplomsko delo, Univ. Ljubl., Bioteh. fak., Odd. agron., Ljubl.: $52 \mathrm{p}$.

Tajnšek, T. (1990): Oljni lan - alternativna izvozna oljnica. Sodobno kmetijstvo, 23, 5: 216218.

Weightman, R., Kindred, D. (2005): Review and analysis of breeding and regulation of hemp anf flax varieties available for growing in the UK. Project NF0530, Final report for the Department for Environment food and rural affairs. ADAS Centre for Sustainable Crop Management: 77 p. 